\title{
Impact of Salt Concentrations on Electricity Generation using Hostel Sludge Based Dual Chambered Microbial Fuel Cell
}

\author{
Anand Parkash*, Shaheen Aziz and Soomro SA \\ Department of Chemical Engineering, Mehran University of Engineering and Technology, Jamshoro, Pakistan
}

\begin{abstract}
Electrical energy needs in Pakistan are expected to continue to rise. The use of petroleum as a source of energy still dominates, although oil reserves in Pakistan are increasingly being depleted. Therefore, there is a need to develop alternative source of sustainable energy, such as Microbial Fuel Cell (MFC). MFC shows another type of renewable energy by changing natural matter into power with the help of microbes. In the present study, varied salt concentrations of a salt bridge in novel MFC design were analyzed. Sewage sludge was utilized, which contains a lot of organic materials and is additionally one of the major sources of ecological contamination, as substrate MFC. Saccharomyces cerverciae sp. $(44 \mathrm{~g})$ was used as a biocatalyst. Methylene blue $(10 \mathrm{ml})$ was used as a mediator and potassium ferricyanide $(100 \mathrm{ml})$ was used as an oxidizing agent for the conversion of sewage sludge into voltage generation using lab-scale double chamber MFC. Varied salt concentrations $(1 \mathrm{M}, 3 \mathrm{M}$ and $5 \mathrm{M}$ of $\mathrm{KCl}$ and $\mathrm{NaCl})$ of salt concentrations of salt bridge in a novel MFC design were analyzed. The maximum generated voltage, current, power, power density and current density with $1 \mathrm{M} \mathrm{KCl}$ were $0.451 \mathrm{~V}, 0.0451,0.0175561 \mathrm{~mW}, 0.000226001 \mathrm{~mW} / \mathrm{m} 2$, $10.5166661 \mu \mathrm{A} / \mathrm{m} 2$ respectively. The MFC was run for a period of 1 day and readings were noted at regular intervals. The results obtained were helpful in designing an optimized MFC.
\end{abstract}

Keywords: Salt bridge; Electrical energy; Microbial fuel cell; Sewage sludge

\section{Introduction}

Due to continuous depletion of the fossil fuels and constant increase in the fuel's price, the world is moving towards the energy catastrophe [1-3]. However, consumption of fossil fuels causes an increase in pollution level which is a major cause of global warming. So requisition of an alternate source of energy is increasing day by day which should be economical, reusable and clean [4,5]. The MFCs provide a promising technology to handle the above two problems by decomposing organic waste to using it [6,7]. For creating a practical world, we need to reduce the utilization of fossil fuels furthermore the pollutants generated. These two points could be accomplished together by treating bio-waste $[8,9]$. In 1911, MC Potter observed that bacteria can be used to produce electrical energy. However, insufficient research was done to advance this technology during 1911-1967. But in 1967, John Davis patents the first MFC technology and possible application and research on MFC was begun after 1990's. Most of the patent was issued in 2000's [9-11]. MFC may be best described as a bioreactor, where microbes act as biocatalyst in metabolizing the organic substances containing the organic carbon to generate electricity $[12,13]$. Electrons are produced by the oxidation of organic materials in which microbes act as catalyst $[14,15]$. The electrons thus produced are transferred to a terminal accepter such as $\mathrm{O}_{2}$, nitrate and sulphate. These terminal electron accepters are get reduced by these electrons [16,17]. A new product is found which can leave the cells when terminal electron acceptors are diffused into the cells. However, there are some microbes specially yeast that can transfer their electrons in the outer space surrounding the cells which are accepted by the awaiting terminal electron acceptors $[18,19]$. These types of microbes are called exogenic and can be utilized to generate electricity within a MFC. The advantages of MFC are easily available exogenic materials which are used as substrate and microbes which act as biocatalyst [20]. It is a simple system and unlike the hydrogen fuel cells, a MFC does not require extremely synchronized division system. It is more effective than enzymatic fuel cell in harvesting electrons from transport system of microbes [21]. This MFC mainly consists of two chambers, one of the chambers, where, oxidation takes place is call anodic chamber (anode) and the other chamber where reduction takes place is called cathodic chamber (cathode) [12-15]. In the presence of oxygen, microbes oxidize organic compounds to produce $\mathrm{CO}_{2}$ and $\mathrm{H}_{2} \mathrm{O}$, but if the reaction takes place in anaerobic environment then microbes decomposes organic materials to produce $\mathrm{CO}_{2}$, while proton and electrons are produced simultaneously [22-24]. Electrons thus produced are transferred to the cathodic chamber via an external circuit while protons are transferred through salt bridge [23]. This flow of electrons generates voltages [24]. Unique design adjustments utilized these years have given huge yields and opened wild in the multidisciplinary MFC research [24,25]. The aim of this research is to take the inward assents of waste materials, like sewage sludge using double chamber MFC for electricity generation and concentrates on the study including different centralizations of salt in salt extension of an arbiter MFC. This paper focuses on the study involving various concentrations of salt in salt bridge of a mediator MFC.

\section{Materials and Methods}

\section{Substrate collection-sewage sludge}

Sewage sludge $(1000 \mathrm{ml})$, which served as the substrate of the MFC was collected from the hostel of MUET Jamshoro, Pakistan.

\section{Cathodic and anodic chamber}

These chambers of the MFC were made up of plastic bottles. Two plastic bottles each of $1000 \mathrm{ml}$ were used for this purpose. The

*Corresponding author: Anand Parkash, Department of Chemical Engineering Mehran University of Engineering and Technology, Jamshoro, Pakistan, Tel: 0333796-2266; E-mail: parwani_anand@yahoo.com

Received August 18, 2015; Accepted August 24, 2015; Published August 28 2015

Citation: Parkash A, Aziz S, Soomro SA (2015) Impact of Salt Concentrations on Electricity Generation using Hostel Sludge Based Dual Chambered Microbial Fuel Cell. J Bioprocess Biotech 5: 252 doi:10.4172/2155-9821.1000252

Copyright: (c) 2015 Parkash A, et al. This is an open-access article distributed under the terms of the Creative Commons Attribution License, which permits unrestricted use, distribution, and reproduction in any medium, provided the original author and source are credited. 
bottle was washed with distilled water and then medium was filled in it. Methylene blue $(10 \mathrm{ml})$, sewage sludge $(1000 \mathrm{ml})$ as a sample and Saccharomyces cervesiae sp. (44 g) added to it.

\section{Salt bridge}

Salt bridge employed here was made with $5 \mathrm{M} \mathrm{NaCl}$ and $10 \%$ Agar. The salt bridge was cast in a PVC pipe $(12 \mathrm{~cm} \times 2 \mathrm{~cm})$. Proper precautions were taken to ensure complete sealing of anodic chamber by means of applying epoxy and wax to ensure anaerobic conditions. The external circuit was completed by connecting a resistor $(10 \Omega)$ between the two leads of the electrodes.

\section{Fabrication and operation of double chamber MFC}

Salt Bridge-Immersed-Air Cathode MFC consisted of a plastic container of capacity 2 liters which served as the anodic chamber (Figure 1). The anodic compartment contained the substrate and the copper electrodes ( 6 " each). The salt bridge served as an electrolyte in transfer of protons. The cathode was immersed in the salt bridge when it was in molten stage to ensure complete surface contact. The $50 \%$ cathode surface was exposed to atmospheric air.

\section{MFC operation}

Substrate (sewage sludge), was added in anaerobic chamber (anodic chamber) and then it is sealed completely for the creation of anaerobic conditions. The MFC was sparged with $\mathrm{CO}_{2}$ before sealing completely to ensure complete removal of oxygen. A batch configuration was employed and readings were taken for a period of 6 days. The readings were taken on a daily basis.

\section{Optimization of salt in salt bridge}

Various strong salts for salt bridge preparation: Two well-known strong salts Sodium Chloride $(\mathrm{NaCl})$ and Potassium Chloride $(\mathrm{KCl})$ were tested for efficacy to transport $\mathrm{H}^{+}$ions in the salt bridge. A dual chambered MFC with sewage sludge as substrate were setup with respective strong salt used for salt bridge fabrication. The cells were run for 6 days and readings were noted at regular intervals.

Molar concentration of salt: Salt bridges were prepared with various Molar concentrations $1,3,5 \mathrm{M} \mathrm{KCl}$ and $\mathrm{NaCl}$ and with agar concentration of $10 \%$. A dual chambered MFC with sewage sludge as substrate was setup with above mentioned varying salt concentrations in salt bridge. The cells were run for 6 days and readings were noted at regular intervals.

Measurement of output: The output of the MFC was expressed by means of voltage (V). For this purpose a digital multimeter was used and was calibrated each time before use. Resistance of $10 \Omega$ was employed in all experiments and hence calculations were based on it. Readings from the multimeter were noted only after a steady and constant value was obtained. The multimeter was connected in series with MFC when measuring voltage.

\section{Results}

\section{Effect on voltage generation by variation in salts concentration}

A two chamber MFC setup was adopted initially with $1 \mathrm{M} \mathrm{KCl}$ solution to make the salt bridge. After that it was checked for $1 \mathrm{M}$ $\mathrm{NaCl}$. Again $\mathrm{KCl}$ and $\mathrm{NaCl}$ were used in different concentration such as $3 \mathrm{M}$ and $5 \mathrm{M}$ for fabricating salt bridge. After comparing the results of difference $\mathrm{KCl}$ and $\mathrm{NaCl}$ concentrations, it was found that the salt bridge made up of $\mathrm{KCl}$ functions better than that of $\mathrm{NaCl}$.
$1 \mathrm{M} \mathrm{KCl}$ and $1 \mathrm{M} \mathrm{NaCl}$ : In this experiment, $1 \mathrm{M} \mathrm{KCl}$ and $1 \mathrm{M} \mathrm{NaCl}$ (Figures 2 and 3) were used to transport $\mathrm{H}^{+}$ions in the salt bridge. The voltage generation was recorded per twenty minutes through the whole day for the substrate sewage sludge. The maximum generated voltage obtained with $1 \mathrm{M} \mathrm{KCl}$ and $1 \mathrm{M} \mathrm{NaCl}$ was $0.451 \mathrm{~V}$ and $0.372 \mathrm{~V}$ (Tables 1 and 2) respectively. The MFC was run for a period of 1 day and readings were noted at regular intervals.

$3 \mathrm{M} \mathrm{KCl}$ and $3 \mathrm{M} \mathrm{NaCl}$ : In the experiment, $3 \mathrm{M} \mathrm{KCl}$ and $3 \mathrm{M} \mathrm{NaCl}$ (Figures 4 and 5) were used to transport $\mathrm{H}^{+}$ions in the salt bridge. The voltage generation was recorded per day throughout the week for the sewage sludge. The maximum generated voltage obtained with $3 \mathrm{M} \mathrm{KCl}$

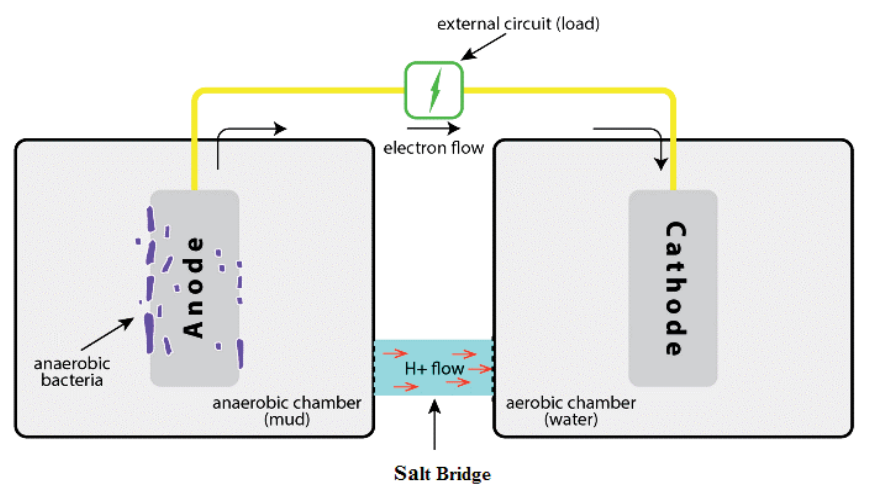

Figure 1: A dual chambered MFC with salt bridge.

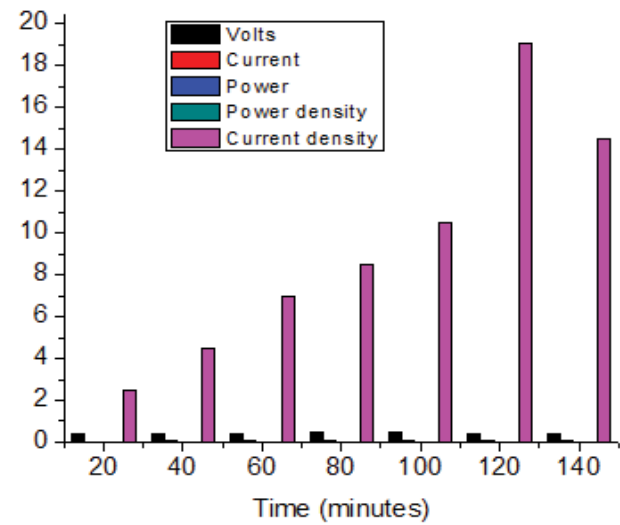

Figure 2: Maximum voltage obtained with $1 \mathrm{M} \mathrm{KCl}$

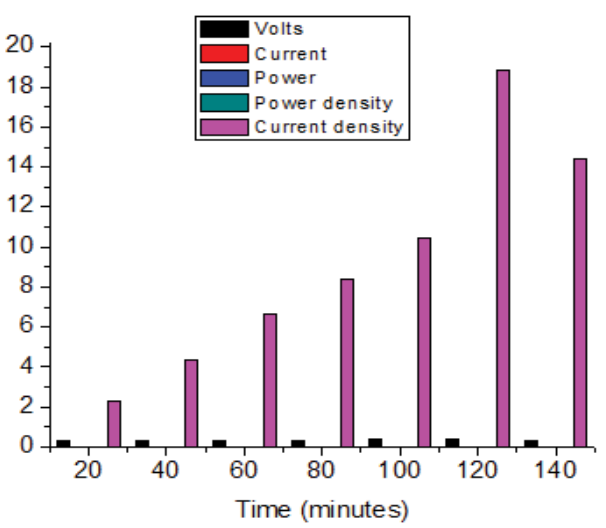

Figure 3: Maximum voltage obtained with $1 \mathrm{M} \mathrm{NaCl}$. 


\begin{tabular}{|c|c|c|c|c|c|}
\hline \multicolumn{6}{|c|}{$1 \mathrm{M} \mathrm{KCl}$} \\
\hline Time (minutes) & $\begin{array}{l}\text { Voltage } \\
\text { (V) }\end{array}$ & $\begin{array}{c}\text { Current } \\
(\mu \mathrm{A})\end{array}$ & $\begin{array}{l}\text { Power } \\
\text { (mW) }\end{array}$ & $\begin{array}{l}\text { Power density } \\
\left(\mathrm{mW} / \mathrm{m}^{2}\right)\end{array}$ & $\begin{array}{l}\text { Current density } \\
\left(\mu \mathrm{A} / \mathrm{m}^{2}\right)\end{array}$ \\
\hline 20 & 0.419 & 0.0419 & 0.0175561 & 0.000195068 & 2.478651168 \\
\hline 40 & 0.427 & 0.0427 & 0.0182329 & 0.000202588 & 4.488135488 \\
\hline 60 & 0.434 & 0.0434 & 0.0188356 & 0.000209284 & 6.966786656 \\
\hline 80 & 0.443 & 0.0443 & 0.0196249 & 0.000218054 & 8.507142954 \\
\hline 100 & 0.451 & 0.0451 & 0.0203401 & 0.000226001 & 10.5166661 \\
\hline 120 & 0.430 & 0.043 & 0.01849 & 0.000205444 & 19.02380906 \\
\hline 140 & 0.425 & 0.0425 & 0.0180625 & 0.000200694 & 14.48576319 \\
\hline
\end{tabular}

Table 1: Maximum voltage obtained with $1 \mathrm{M} \mathrm{KCl}$.

\begin{tabular}{|c|c|c|c|c|c|}
\hline \multicolumn{6}{|c|}{$1 \mathrm{M} \mathrm{KCl}$} \\
\hline Time (minutes) & $\begin{array}{l}\text { Voltage } \\
\text { (V) }\end{array}$ & $\begin{array}{c}\text { Current } \\
(\mu \mathrm{A})\end{array}$ & $\begin{array}{l}\text { Power } \\
\text { (mW) }\end{array}$ & $\begin{array}{l}\text { Power density } \\
\left(\mathrm{mW} / \mathrm{m}^{2}\right)\end{array}$ & $\begin{array}{c}\text { Current density } \\
\left(\mu \mathrm{A} / \mathrm{m}^{2}\right)\end{array}$ \\
\hline 20 & 0.419 & 0.0419 & 0.0175561 & 0.000195068 & 2.478651168 \\
\hline 40 & 0.427 & 0.0427 & 0.0182329 & 0.000202588 & 4.488135488 \\
\hline 60 & 0.434 & 0.0434 & 0.0188356 & 0.000209284 & 6.966786656 \\
\hline 80 & 0.443 & 0.0443 & 0.0196249 & 0.000218054 & 8.507142954 \\
\hline 100 & 0.451 & 0.0451 & 0.0203401 & 0.000226001 & 10.5166661 \\
\hline 120 & 0.430 & 0.043 & 0.01849 & 0.000205444 & 19.02380906 \\
\hline 140 & 0.425 & 0.0425 & 0.0180625 & 0.000200694 & 14.48576319 \\
\hline
\end{tabular}

Table 2: Maximum voltage obtained with $1 \mathrm{M} \mathrm{NaCl}$.

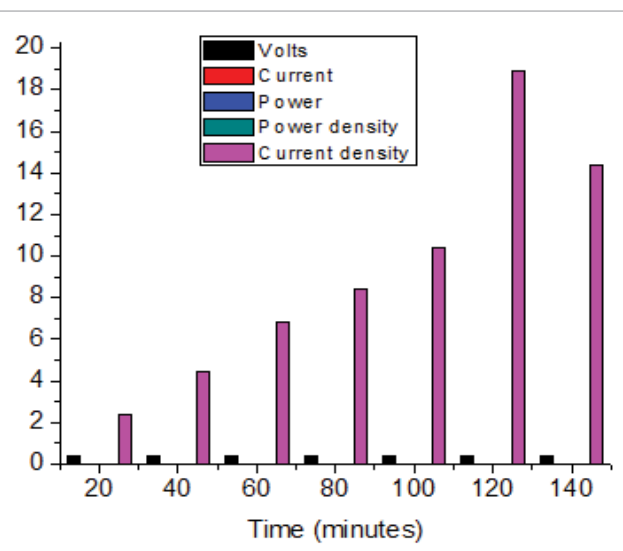

Figure 4: Maximum voltage obtained with $3 \mathrm{M} \mathrm{KCl}$.

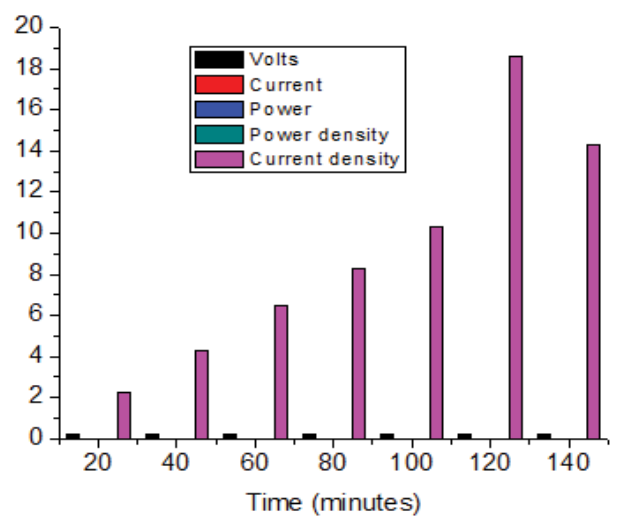

Figure 5: Maximum voltage obtained with $3 \mathrm{M} \mathrm{NaCl}$.

and $3 \mathrm{M} \mathrm{NaCl}$ was $387 \mathrm{~V}$ and $248 \mathrm{~V}$ (Tables 3 and 4) respectively. The MFC was run for a period of 1 day and readings were noted at regular intervals.
$5 \mathrm{M} \mathrm{KCl}$ and $5 \mathrm{M} \mathrm{NaCl}$ : In the experiment, $5 \mathrm{M} \mathrm{KCl}$ and $5 \mathrm{M} \mathrm{NaCl}$ (Figures 6 and 7) were used to transport $\mathrm{H}^{+}$ions in the salt bridge. The maximum generated voltage obtained with $5 \mathrm{M} \mathrm{KCl}$ and $5 \mathrm{M}$ $\mathrm{NaCl}$ is $356 \mathrm{~V}$ and $232 \mathrm{mV}$ (Tables 5 and 6) respectively. The MFC was run for a period of 7 days and readings were noted at regular intervals

\section{Discussion}

The design of a dual chamber MFC is highly critical and needs best optimization. The Two Chamber MFC used in primitive studies was replaced by the Salt bridge immersed air cathode MFC. The two chamber system has a disadvantage of increased internal resistance and whereas in the MFC, the internal resistance is significantly lowered. MFC is a novel design that increased the cathode potential with increased oxygen availability and enhanced surface area contact with the salt bridge. Large scale MFCs can basically employ air cathode MFC as it increases the output and also decreases the task of concern in chamber design, space and thereby cost. As the primary designing application for MFC will be electricity generation from sewage sludge, reduce the concern over the design, will be vital for the operation of MFC. The main challenge in improving voltage generation is to make framework plans that diminish resistance. The study involved Salt Bridge which is the most economical component in the dual chamber MFC. For the first part of the study, $\mathrm{KCl}$ and $\mathrm{NaCl}$ were compared for use as strong salt in salt bridge. The study clearly showed that there was not much difference between these salts in terms of voltage output. Molar concentration of salt is critical since the transfer of protons through the salt bridge is facilitated by the dissociated ions in it. The experiments showed that, with increase in molar concentration the current decreases. Optimum results were obtained for salt bridge fabricated using $1 \mathrm{M} \mathrm{NaCl}$. It produced a maximum voltage of 0.372 $\mathrm{V}$. The membrane based MFC needs membrane replacement due to fouling which decreases the lifetime of its use in MFC. The salt bridge MFC also needs to be studied extensively, as the literature available on salt bridge based MFC is not sufficient. However, the magnitude of electron transfer should be higher and earlier than the respiratory 
Citation: Parkash A, Aziz S, Soomro SA (2015) Impact of Salt Concentrations on Electricity Generation using Hostel Sludge Based Dual Chambered Microbial Fuel Cell. J Bioprocess Biotech 5: 252 doi:10.4172/2155-9821.1000252

Page 4 of 6

\begin{tabular}{|c|c|c|c|c|c|}
\hline \multicolumn{6}{|c|}{$1 \mathrm{M} \mathrm{NaCl}$} \\
\hline Time (minutes) & $\begin{array}{l}\text { Voltage } \\
\text { (V) }\end{array}$ & $\begin{array}{c}\text { Current } \\
(\mu \mathrm{A})\end{array}$ & $\begin{array}{l}\text { Power } \\
(\mathrm{mW})\end{array}$ & $\begin{array}{l}\text { Power density } \\
\qquad\left(\mathrm{mW} / \mathrm{m}^{2}\right)\end{array}$ & $\begin{array}{c}\text { Current density } \\
\left(\mu \mathrm{A} / \mathrm{m}^{2}\right)\end{array}$ \\
\hline 20 & 0.281 & 0.0281 & 0.0078961 & 8.77344E-05 & 2.317083834 \\
\hline 40 & 0.289 & 0.0289 & 0.0083521 & $9.28011 \mathrm{E}-05$ & 4.326344901 \\
\hline 60 & 0.316 & 0.0316 & 0.0099856 & 0.000110951 & 6.643428736 \\
\hline 80 & 0.337 & 0.0337 & 0.0113569 & 0.000126188 & 8.382183088 \\
\hline 100 & 0.372 & 0.0372 & 0.0138384 & 0.00015376 & 10.42319216 \\
\hline 120 & 0.356 & 0.0356 & 0.0126736 & 0.000140818 & 18.80537525 \\
\hline 140 & 0.349 & 0.0349 & 0.0121801 & 0.000135334 & 14.39621543 \\
\hline
\end{tabular}

Table 3: Maximum voltage obtained with $3 \mathrm{M} \mathrm{KCl}$.

\begin{tabular}{|c|c|c|c|c|c|}
\hline \multicolumn{6}{|c|}{$3 \mathrm{M} \mathrm{NaCl}$} \\
\hline Time (minutes) & $\begin{array}{l}\text { Voltage } \\
\text { (V) }\end{array}$ & $\begin{array}{c}\text { Current } \\
(\mu \mathrm{A})\end{array}$ & $\begin{array}{l}\text { Power } \\
(\mathrm{mW})\end{array}$ & $\begin{array}{l}\text { Power density } \\
\qquad\left(\mathrm{mW} / \mathrm{m}^{2}\right)\end{array}$ & $\begin{array}{l}\text { Current density } \\
\qquad\left(\mu \mathrm{A} / \mathrm{m}^{2}\right)\end{array}$ \\
\hline 20 & 0.224 & 0.0224 & 0.0050176 & 5.57511E-05 & 2.251473351 \\
\hline 40 & 0.228 & 0.0228 & 0.0051984 & 0.00005776 & 4.25605616 \\
\hline 60 & 0.235 & 0.0235 & 0.0055225 & 6.13611E-05 & 6.507529511 \\
\hline 80 & 0.237 & 0.0237 & 0.0056169 & 0.00006241 & 8.26637931 \\
\hline 100 & 0.248 & 0.0248 & 0.0061504 & 6.83378E-05 & 10.27901874 \\
\hline 120 & 0.238 & 0.0238 & 0.0056644 & 6.29378E-05 & 18.54539805 \\
\hline 140 & 0.230 & 0.023 & 0.00529 & 5.87778E-05 & 14.25834878 \\
\hline
\end{tabular}

Table 4: Maximum voltage obtained with $3 \mathrm{M} \mathrm{NaCl}$.

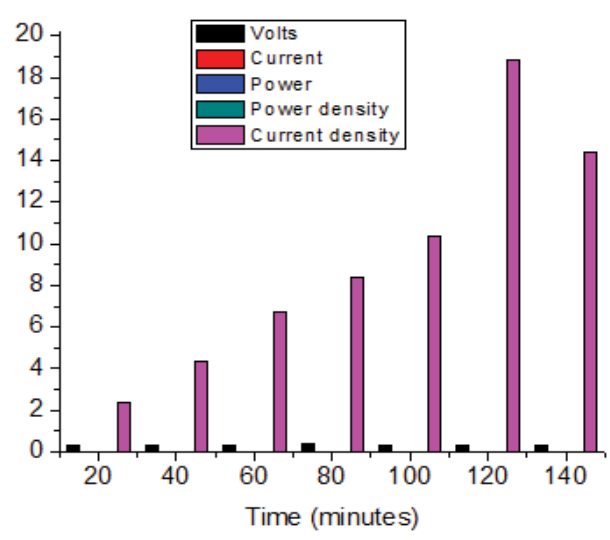

Figure 6: Maximum voltage obtained with $5 \mathrm{M} \mathrm{KCl}$

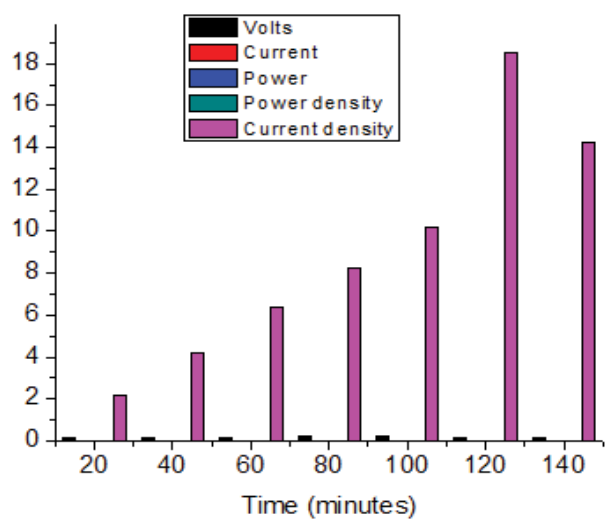

Figure 7: Maximum voltage obtained with $5 \mathrm{M} \mathrm{NaCl}$.

chain. Identifying a potential substrate that is enormously available, low cost, high energy yields and renewable for alternate energy production is imperative. Wastes with high organic content are a good candidature of choice in MFC as a substrate. Highly homogenized substrate and availability for microbial consortium can be attributed to the maximum current obtained. 
Citation: Parkash A, Aziz S, Soomro SA (2015) Impact of Salt Concentrations on Electricity Generation using Hostel Sludge Based Dual Chambered Microbial Fuel Cell. J Bioprocess Biotech 5: 252 doi:10.4172/2155-9821.1000252

Page 5 of 6

\begin{tabular}{|c|c|c|c|c|c|}
\hline \multicolumn{6}{|c|}{$5 \mathrm{M} \mathrm{KCl}$} \\
\hline Time (minutes) & $\begin{array}{l}\text { Voltage } \\
\text { (V) }\end{array}$ & $\begin{array}{c}\text { Current } \\
(\mu \mathrm{A})\end{array}$ & $\begin{array}{l}\text { Power } \\
\text { (mW) }\end{array}$ & $\begin{array}{l}\text { Power density } \\
\qquad\left(\mathrm{mW} / \mathrm{m}^{2}\right)\end{array}$ & $\begin{array}{l}\text { Current density } \\
\qquad\left(\mu \mathrm{A} / \mathrm{m}^{2}\right)\end{array}$ \\
\hline 20 & 0.317 & 0.0317 & 0.0100489 & 0.000111654 & 2.358860554 \\
\hline 40 & 0.319 & 0.0319 & 0.0101761 & 0.000113068 & 4.361189168 \\
\hline 60 & 0.329 & 0.0329 & 0.0108241 & 0.000120268 & 6.720049722 \\
\hline 80 & 0.356 & 0.0356 & 0.0126736 & 0.000140818 & 8.404414418 \\
\hline 100 & 0.343 & 0.0343 & 0.0117649 & 0.000130721 & 10.38919562 \\
\hline 120 & 0.341 & 0.0341 & 0.0116281 & 0.000129201 & 18.79361004 \\
\hline 140 & 0.324 & 0.0324 & 0.0104976 & 0.00011664 & 14.36701424 \\
\hline
\end{tabular}

Table 5: Maximum voltage obtained with $5 \mathrm{M} \mathrm{KCl}$

\begin{tabular}{|c|c|c|c|c|c|}
\hline \multicolumn{6}{|c|}{$5 \mathrm{M} \mathrm{NaCl}$} \\
\hline Time (minutes) & $\begin{array}{l}\text { Voltage } \\
\text { (V) }\end{array}$ & $\begin{array}{c}\text { Current } \\
(\mu \mathrm{A})\end{array}$ & $\begin{array}{l}\text { Power } \\
(\mathrm{mW})\end{array}$ & $\begin{array}{l}\text { Power density } \\
\qquad\left(\mathrm{mW} / \mathrm{m}^{2}\right)\end{array}$ & $\begin{array}{l}\text { Current density } \\
\qquad\left(\mu \mathrm{A} / \mathrm{m}^{2}\right)\end{array}$ \\
\hline 20 & 0.175 & 0.0175 & 0.0030625 & 3.40278E-05 & 2.195596528 \\
\hline 40 & 0.176 & 0.0176 & 0.0030976 & 3.44178E-05 & 4.196732018 \\
\hline 60 & 0.184 & 0.0184 & 0.0033856 & 3.76178E-05 & 6.392328546 \\
\hline 80 & 0.232 & 0.0232 & 0.0053824 & 5.98044E-05 & 8.260642204 \\
\hline 100 & 0.196 & 0.0196 & 0.0038416 & 4.26844E-05 & 10.21948428 \\
\hline 120 & 0.189 & 0.0189 & 0.0035721 & 0.00003969 & 18.48012649 \\
\hline 140 & 0.184 & 0.0184 & 0.0033856 & 3.76178E-05 & 14.20582322 \\
\hline
\end{tabular}

Table 6: Maximum voltage obtained with $5 \mathrm{M} \mathrm{NaCl}$.

\section{Conclusion}

The study involved double chambered MFC using Salt Bridge which is the most economical component in the MFC. For the first part of the study, $\mathrm{KCl}$ and $\mathrm{NaCl}$ were compared for use as strong salt in salt bridge. Molar concentration of salt is critical since the transfer of protons through the salt bridge is facilitated by the dissociated ions in it. The experiments showed that, with increase in molar concentration the current decreases. Optimum results were obtained for salt bridge fabricated using $1 \mathrm{M} \mathrm{KCl}$ and $\mathrm{NaCl}$. It produced a maximum voltage $0.451 \mathrm{~V}$ and $0.372 \mathrm{~V}$ respectively. In this double chamber MFC using Saccharomyces cerevisiae was used as biocatalyst. Anode chamber was kept up in batch mode and another side cathode chamber was maintained at continuous mode. Our results have indicated that the salt bridge based MFC needs membrane replacement due to fouling which decreases the lifetime of its use in MFC. The salt bridge MFC also needs to be studied extensively, as the literature available on salt bridge based MFC is not sufficient.

\section{Acknowledgements}

The authors wish to express their sincere thanks for the lab facilities provided for this work in the Department of Chemical Engineering, Mehran University of Engineering and Technology, Jamshoro, Pakistan.

\section{References}

1. Logan BE (2008) Microbial Fuel Cells, John Wiley \& Sons, New York.

2. Booth D (1993) Understanding Fuel Cells, Home Power\#35, pp: 37-40.

3. Lewis NS, Nocera DG (2006) Powering the planet: chemical challenges in solar energy utilization. Proc Natl Acad Sci USA 103: 15729-15735.

4. Bullen RA, Arnot TC, Lakeman JB, Walsh FC (2006) Biofuel cells and their development. Biosens Bioelectron 21: 2015-2045.

5. Renewable Energy World (2001) Renewable fuel cell power from biogas. James \& James Ltd.

6. Lui H, Logan BE (2004) Production of electricity during wastewater treatment using a single chamber microbial fuel cell. Environ Sci Tech 38: 2281-2285.

7. Bunnetto HP (1990) Bug power-electricity from microbes. In A. Scott (editor) Frontiers of Science. Blackwell Publishing, Cambridge, MA, USA, pp: 66-82.
8. Ieropoulos IA, Greenman J, Melhuish C, Hart J (2005) Comparative study of three types of microbial fuel cell. Enzyme Microb Tech 37: 238-245.

9. Davis F, Higson SPJ (2007) Biofuel cells-Recent advances and applications Biosens Bioelectron 22: 1224-1235

10. Pham TH, Rabaey K, Aelterman $P$, Clauwaert $P$, De Schamphelaire L, et al. (2006) Microbial fuel cells in relation to conventional anaerobic digestion technology. Eng Life Sci 6: 285-292.

11. Logan BE, Regan JM (2006) Electricity-producing bacterial communities in microbial fuel cells. Trends Microbiol 14: 512-518.

12. Chaudhuri SK, Lovely DR (2003) Electricity generation by direct oxidation of glucose in mediatorless microbial fuel cells. Nat Biotechnol 21: 1229-1232.

13. Picioreanu C, Kreft JU, van Loosdrecht MCM (2004) Particle-Based Multidimensional Multispecies Biofilm Model. Appl Environ Microbiol 70: 3024.

14. Picioreanu C, Katuri KP, Head IM, van Loosdrecht MCM, Scott K (2008) Mathematical model for microbial fuel cells with anodic biofilms and anaerobic digestion. Water Sci Technol 57: 965

15. Ramanavicius A, Kausaitea A, Ramanaviciene A (2008) Enzymatic biofuel cel based on anode and cathode powered by ethanol, Biosens Bioelectron 24 767-772.

16. Jiansheng H, Ping Y, Yong G, Zhang K (2011) Electricity generation during wastewater treatment: An approach using an AFB-MFC for alcohol distillery wastewater. Desalination 276: 373-378.

17. Chang IS, Jang JK, Gil GC, Kim M, Kim HJ, et al. (2004) Continuous determination of biochemical oxygen demand using microbial fuel cell type biosensor. Biosens Bioelectron 19: 607-613.

18. Chang IS, Moon H, Jang JK, Kim BH (2005) Improvement of a microbial fuel cell performance as a BOD sensor using respiratory inhibitors. Biosens Bioelectron 20: 1856-1859.

19. Cheng X, Shi Z, Glass N, Zhang L, Zhang J, et al. (2004) A review of PEM hydrogen fuel cell contamination: impacts, mechanisms, and mitigation. $J$ Power Sources 305: 1280-1283.

20. Gong M, Liu X, Trembly J, Johnson C (2007) Sulfur-tolerant anode materials for solid oxide fuel cell application. J Power Sources 168: 289-298.

21. Kim IS, Chae KJ, Choi MJ, Verstraete W (2008) Microbial fuel cells: recent advances, bacterial communities and application beyond electricity generation. Environ Eng Res 13: 51-65. 
Citation: Parkash A, Aziz S, Soomro SA (2015) Impact of Salt Concentrations on Electricity Generation using Hostel Sludge Based Dual Chambered Microbial Fuel Cell. J Bioprocess Biotech 5: 252 doi:10.4172/2155-9821.1000252

22. Kim JR, Min B, Logan BE (2005) Evaluation of procedures to acclimate a microbial fuel cell for electricity generation. Appl Microbiol Biotechnol 68: 23-30.

23. Lee J, Phung NT, Chang IS, Kim BH, Sung HC (2003) Use of acetate for enrichment of electrochemically active microorganisms and their 16S rDNA analyses. FEMS Microbiol Lett 223: 185-191.
24. Liu H, Cheng S, Logan BE (2003) Production of electricity from acetate or butyrate using a single-chamber microbial fuel cell. Environ Sci Tech 39: 658662.

25. Pham TH, Jang JK, Chang IS, Kim BH (2008) Improvement of cathode reaction of a mediator less microbial fuel cell. J Microbiol Biotechnol 14: 324-329. 